\title{
Uji sitotoksisitas dan antiproliferatif ekstrak etanol daun leunca (Solanum nigrum, L.) terhadap sel raji
}

\author{
Rahma Dona ${ }^{1,2}$, Nanik Sulistyani ${ }^{2}$, Laela Hayu Nurani ${ }^{2}$ \\ ${ }^{1}$ Sekolah Tinggi Ilmu Farmasi Riau (STIFAR) \\ Jl.Kamboja Simpang Baru Panam, Pekanbaru \\ ${ }^{2}$ Fakultas Farmasi Universitas Ahmad Dahlan \\ Jl.Prof. Dr. Soepomo, Janturan, Yogyakarta
}

Submitted: 24-02-2016

Reviewed: 26-08-2016

Accepted: 03-11-2016

\begin{abstract}
ABSTRAK
Leunca (Solanum nigrum, L.) merupakan salah satu bahan alam yang digunakan masyarakat untuk pengobatan tradisional sebagai antipiretik, hipotensif dan antikanker. Penelitian ini bertujuan untuk mengetahui aktivitas antikanker ekstrak etanol daun leunca dalam hal kemampuannya menghambat pertumbuhan sel kanker Raji. Ekstrak etanol daun leunca diperoleh dari proses penyarian serbuk daun leunca menggunakan pelarut etanol dengan alat Soxhlet. Uji sitotoksisitas dilakukan dengan menginkubasi sel Raji yang memiliki kepadatan $2 \times 10^{4}$ dengan perlakuan ekstrak etanol daun leunca (Solanum nigrum, L.) dengan beberapa seri kadar yaitu 500; 250; 125; 62,$5 ; 31,25 ; 15,62 ; 7,81$ dan 3,90 $\mu \mathrm{g} / \mathrm{mL}$. Pengujian dilakukan dengan metode MTT kemudian dihitung persen kematiannya. Nilai $\mathrm{IC}_{50}$ dihitung dengan menggunakan analisa probit. Penelitian dilanjutkan dengan uji

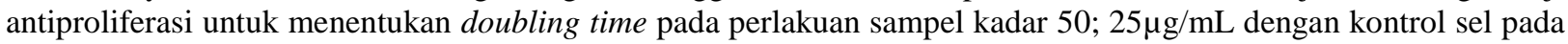
jam ke-24, 48 dan 72. Hasil penelitian menunjukkan bahwa ekstrak etanol daun leunca bersifat sitotoksik terhadap sel kanker Raji dengan harga $\mathrm{IC}_{50}$ sebesar $59,22 \mu \mathrm{g} / \mathrm{mL}$. Hasil uji antiproliferasi menunjukkan adanya penghambatan pertumbuhan pada perlakuan ekstrak dengan nilai doubling time sebesar 69,56 jam pada kadar 50 $\mu \mathrm{g} / \mathrm{mL} ; 60,00$ jam pada kadar $25 \mu \mathrm{g} / \mathrm{mL}$, sedangkan pada kontrol sel adalah 44,98 jam.
\end{abstract}

Kata kunci: daun leunca, ekstrak etanol, uji sitotoksisitas, uji antiproliferasi

\begin{abstract}
Leunca (Solanum nigrum, L.) is one of the medicinal plant which used as antipyretic, hypotensive and anticancer. The aim of this research was to know an anticancer activity of ethanol extract of leunca leaves, emphasized on an ability to inhibit the growth of Raji celline. Ethanolic extract was prepared from maceration of leunca leaf powder using ethanol and evaporated by Soxhlet instrument. Citotoxicity test was done by incubating Raji celline at a density of $2 \times 10^{4}$ with treatment using ethanol extract from leunca (Solanum nigrum L.) leaf in several concentration $500 ; 250 ; 125 ; 62.5 ; 31.25 ; 15.62 ; 7.81$ and $3.90 \mu \mathrm{g} / \mathrm{mL}$. A test was done by MTT method and the percentage of cell mortality was calculated. The $\mathrm{IC}_{50}$ values were calculated using probit analysis. The research continued with antiproliferation test on treatment sample concentration $50 ; 25 \mu \mathrm{g} / \mathrm{mL}$ with cell control for 24,48 , and 72 hours.The result of research indicate that ethanol extract of leunca leaves had cytotoxic effect towards Raji cell with $\mathrm{IC}_{50}$ values $59.22 \mu \mathrm{g} / \mathrm{mL}$. The result of antiproliferation test showed that there were the growth of inhibitation on treatment sample with doubling time values of 69.56 hour at concentration $50 \mu \mathrm{g} / \mathrm{mL} ; 60.00$ hour at concentration $25 \mu \mathrm{g} / \mathrm{mL}$, and doubling time of cell control is 44.98 hour.
\end{abstract}

Keywords: leunca leaf, ethanol extract, cytotoxicity assay, antiproliferative assay

\author{
Penulis korespondesi: \\ Rahma Dona \\ Sekolah Tinggi Ilmu Farmasi Riau (STIFAR) \\ Jl.Kamboja Simpang Baru Panam \\ Email: rdona1985@gmail.com
}




\section{PENDAHULUAN}

Penyakit kanker merupakan salah satu penyebab kematian utama di seluruh dunia. Pada tahun 2012, sekitar 8,2 juta kematian disebabkan oleh kanker. Kanker paru, hati, perut, kolorektal, dan kanker payudara adalah penyebab terbesar kematian akibat kanker setiap tahunnya. Lebih dari 30\% dari kematian akibat kanker disebabkan oleh lima faktor risiko perilaku dan pola makan, yaitu indeks massa tubuh tinggi, kurang konsumsi buah dan sayur, kurang aktivitas fisik, penggunaan rokok, dan konsumsi alkohol berlebihan. Merokok merupakan faktor risiko utama kanker yang menyebabkan terjadinya lebih dari 20\% kematian akibat kanker di dunia dan sekitar 70\% kematian akibat kanker paru di seluruh dunia. Diperkirakan kasus kanker tahunan akan meningkat dari 14 juta pada 2012 menjadi 22 juta dalam dua dekade berikutnya (Kemenkes, 2015)

Limfoma merupakan salah satu jenis kanker dalam kelenjar getah bening atau organ lain dari sistem limfatik. Limfoma merupakan kanker urutan ketiga paling cepat tumbuh, berkembang, setelah kanker kulit dan kanker paru-paru. Diperkirakan sekitar 1,5 juta penduduk dunia hidup dengan limfoma non Hodgkin (LNH), dan sekitar 300.000 orang setahun meninggal karena penyakit ini. Di Indonesia, limfoma atau lebih sering disebut kanker kelenjar masuk kelompok 10 besar kanker ganas (Hukom, 2005). Limfoma dibagi dalam dua kelompok utama, yaitu: limfoma non Hodgkin (LNH) dan limfoma Hodgkin (LH) (Katzung, 2004). Sel Raji ditemukan pada pasien dengan limfoma Burkitt, yaitu salah satu jenis limfoma non Hodgkin yang bersifat agresif. LNH agresif tumbuh lebih cepat, lebih menimbulkan gejala daripada LNH, dan biasanya membutuhkan pengobatan segera, namun sering memberikan respon sangat baik terhadap pengobatan (Hukom, 2005). Kanker limfoma non-hodgkin berada pada urutan ke-10 penyakit kanker terbanyak pada tahun 2010 dan 2011 (Kemenkes, 2015).

Uji sitotoksisitas merupakan suatu uji pendahuluan untuk mengetahui potensi ketoksikan senyawa terhadap sel kanker. Evaluasi aktivitas antikanker dari buah Solanum nigrum,L menunjukkan penghambatan pada kultur sel kanker HeLa dengan $\mathrm{IC}_{50}$ sebesar 265,0 $\mu \mathrm{g} / \mathrm{mL}$ (Patel et al., 2005). Kandungan kimia dari tanaman Solanum nigrum,L antara lain solasonine, solasodine, solamargine, dan solanine, dimana senyawa tersebut merupakan penghambat pertumbuhan sel kanker yang tak terkendali. Kandungan kimia lainnya adalah glikoalkaloid, solanidine, diosgenine, tigogenine, juga sedikit atropine, saponin dan minyak lemak (Dalimartha, 2006). Dari uji sitotoksik mengindikasikan bahwa kandungan utama senyawa antikanker pada Solanum nigrum, L adalah solamargine (Hu et al., 1999). Solamargin diketahui dapat memodulasi protein TNFRs dan bcl-2, dan potensial sebagai agen antikanker untuk sel kanker yang resisten TNFs and Bcl-2 (Liu et al., 2004). Selain itu solamargine menurunkan regulasi HER2 dan meningkatkan regulasi Fas dan ekspresi tumor necrosis factor receptor (TNFR) sehingga memacu jalur apoptosis sel yang termediasi mitokondria dan mensensitisasi nonsmall cell lung cancer (NSCLC) H441 dan A549 (Liang et al., 2008). Pada penelitian lainnya, ekstrak air daun Solanum nigrum yang dikombinasikan dengan obat kemoterapi cisplatin, doxorubicin, docetaxel, dan 5fluorouracil dapat meningkatkan sitotoksisitas sel tumor pada kanker kolorektal (Tai et al., 2013)

Berdasarkan data empiris dan latar belakang tersebut, maka tanaman leunca sangat penting untuk diteliti dan dikembangkan lebih lanjut pada sel kanker lainnya untuk mengetahui apakah memiliki potensi dan selektifitas terhadap sel kanker lainnya, yaitu pada sel Raji.

\section{METODE PENELITIAN \\ Alat dan Bahan}

Alat yang digunakan: microplate 96 sumuran, ELISA reader, tissue culture flask, haemocytometer, seperangkat alat Soxhlet, sentrifuge, magnetic stirrer, inkubator, LAF, mikroskop, tabung conical. Bahan yang digunakan dalam penelitian ini adalah ekstrak etanol daun leunca (Solanum nigrum,L), sel kanker Raji yang diperoleh dari stok Laboratorium Penelitian dan Pengujian Terpadu (LPPT) UGM Yogyakarta, media kultur Rosewell Park Memorial Institut (RPMI) 1640, fungison, penicillin-streptomisin (Penstrep), Fetal Bovine Serum (FBS) sebagai nutrisi sel, aqua destilata, $\mathrm{NaHCO}_{3}, \mathrm{HEPES}$ (N-2-hydroxyethyl piperazine-N-2-ethane sulfonic acid) teknis, MTT, Sodium Duodecyl Sulphate (SDS), NaOH 1 N, HCl 1 $\mathrm{N}$, etanol $70 \%$, tripsin EDTA. 


\section{Jalannya Penelitian \\ Identifikasi tanaman}

Identifikasi daun Solanum nigrum, L. dilakukan di Laboratorium Farmakognosi Bagian Biologi Farmasi Fakultas Farmasi Universitas Gadjah Mada Yogyakarta.

\section{Penyiapan sediaan uji}

Pembuatan ekstrak etanol daun leunca (Solanum nigrum, L.) dilakukan dengan menggunakan alat Soxhlet. Sebagai pelarut digunakan etanol $70 \%$ yang berfungsi untuk melarutkan senyawa yang akan diekstraksi. Proses ekstraksi dilakukan sampai zat aktif yang terdapat dalam daun leunca habis (ditandai dengan cairan penyari dalam rumah siput yang telah tidak berwarna) dengan kecepatan 6-8 sirkulasi/jam. Filtrat yang diperoleh dikumpulkan dan dipindahkan ke dalam cawan porselin yang sebelumnya telah ditimbang kemudian diuapkan pelarutnya di atas penangas air dengan pemanasan rendah. Proses ini dilakukan hingga ekstrak menjadi kental dan tidak memberikan bau etanol lagi. Ekstrak ini kemudian ditimbang dan disimpan dalam lemari es.

\section{Pembuatan larutan sediaan uji}

Pembuatan larutan sediaan uji diawali dengan pembuatan stok larutan uji, yaitu dengan menimbang 0,040 g ekstrak etanol daun leunca kemudian dilarutkan dalam $1 \mathrm{ml}$ media (RPMI 1640). Dari larutan stok tersebut dapat dibuat seri kadar ekstrak etanol daun leunca dalam media RPMI. Pembuatan larutan uji ini dilakukan di dalam Laminar Air Flow Cabinet secara aseptis.

\section{Preparasi sel raji \\ Pembuatan media biakan sel raji}

Pembuatan media biakan sel Raji (RPMI 1640) dibuat dengan cara serbuk RPMI 1640 sebanyak 10,40 gram untuk satu liter dilarutkan dalam aquabidest kira-kira $800 \mathrm{~mL}$, ditambah 2 gram natrium bikarbonat dan HEPES 2 gram, tambahkan aquabidest sampai satu liter kemudian diaduk menggunakan stirrer sampai semua serbuk larut. Larutan dibuat sampai PH 7,2. Jika terlalu asam ditambahkan $\mathrm{NaOH}$ $1 \mathrm{~N}$ dan jika terlalu basa ditambah HCL $1 \mathrm{~N}$. Media disterilkan dengan metode aseptis menggunakan penyaringan pori $0,2 \mu \mathrm{m}$ di LAF, kemudian disimpan pada suhu $4^{\circ} \mathrm{C}$ untuk penggunaan selanjutnya (Junedi, S et al, 2010).

\section{Pengadaan Sel Raji}

Sel Raji diambil dari tangki nitrogen cair, segera dicairkan dalam penangas air pada suhu $37^{\circ} \mathrm{C}$ sampai gumpalan di dalam vial mencair. Di dalam Laminar Air Flow (LAF), sel Raji dimasukkan dalam tabung conical steril yang berisi media biakan RPMI 1640 kemudian disentrifuge dengan kecepatan 1500 rpm selama 5 menit. Supernatan yang diperoleh dibuang, pelet diambil kemudian sel ditumbuhkan dalam beberapa (3-4) buah tissue culture flask dalam media RPMI 1640 yang mengandung 10\% FBS. Flask kemudian diinkubasi dalam inkubator pada suhu $37^{\circ} \mathrm{C}$ dengan aliran $5 \% \mathrm{CO}_{2}$ dengan tutup flask dikendorkan untuk mengoptimalkan aerasi yang sangat penting untuk pertumbuhan sel. Medium diganti setelah 3-4 hari dan sel ditumbuhkan lagi hingga konfluen dan jumlahnya cukup untuk penelitian. Sel dipanen setelah konfluen yang ditandai dengan sel memenuhi tissue culture flask.

\section{Pemanenan dan Perhitungan Sel}

Sel dipanen setelah konfluen ditandai dengan sel memenuhi tissue culture flask. Sel dilepaskan dari dinding flask dengan cara media disedot dengan pipet pasteur kemudian disemprotkan dengan tekanan tinggi ke dinding flask hingga bintik-bintik putih di dinding flask lepas. Sel yang telah dilepaskan dimasukkan ke dalam tabung conical dan di sentrifuge $1500 \mathrm{rpm}$ selama 5 menit. Pelet putih di ambil, kemudian supernatannya dibuang. Pelet putih adalah koloni sel yang mengendap karena pemusingan. Pelet dicuci dengan medium kemudian ditambah sedikit media kemudian diresuspensi dan dihitung jumlah selnya menggunakan haemocytometer di bawah mikroskop. Jumlah sel dapat dihitung dengan rumus:

Jumlah sel dalam 4 bilik

$$
\text { Jumlah Sel = - } 4
$$




\section{Uji sitotoksisitas}

Metode yang digunakan dalam uji sitotoksisitas ini adalah metode MTT (3-(4-5- dimetiltiazol-2 yl) - 2,5 - difenil tetrazolium bromida) karena dapat mempermudah pengamatan. Dari uji sitotoksisitas ini dapat diketahui kisaran kadar zat yang berefek toksik terhadap sel kanker.

Sebanyak $100 \mu \mathrm{L}$ suspensi sel Raji didistribusikan dengan kepadatan sel $2 \times 10^{4}$ ke dalam microplate 96 sumuran, kemudian pada tiap sumuran di tambahkan $100 \mu \mathrm{L}$ larutan sediaan uji dalam media dengan konsentrasi awal sebesar $1000 ; 500 ; 250 ; 125 ; 62,5 ; 31,25 ; 15,625$ dan $7,8125 \mu \mathrm{g} / \mathrm{mL}$ sehingga diperoleh konsentrasi akhir 500; 250; 125; 62,5; 31,25; 15,625; 7,8125 dan 3,90625 $\mu \mathrm{g} / \mathrm{mL}$ karena terencerkan menjadi separuhnya. Sel yang telah diberi perlakuan di inkubasi pada suhu $37^{\circ} \mathrm{C}$ selama 24 jam, setelah itu tiap sumuran diberi reagen MTT sejumlah $10 \mu \mathrm{L}$. MTT akan bereaksi dengan sel hidup dan akan dipecah menjadi garam formazan yang tidak larut oleh enzim dehidrogenase, empat jam kemudian dilanjutkan dengan pemberian reagen stopper (SDS 10\% dalam $\mathrm{HCl} 0,01 \mathrm{~N}$ ) kemudian diinkubasi semalam. Intensitas warna yang terjadi dibaca dengan ELISA reader pada panjang gelombang $550 \mathrm{~nm}$ (Meiyanto et al, 2003). Pengukuran dilakukan pada panjang gelombang $550 \mathrm{~nm}$, yaitu panjang gelombang optimum agar diperoleh pengukuran yang peka dan spesifik (Burgess, 1995).

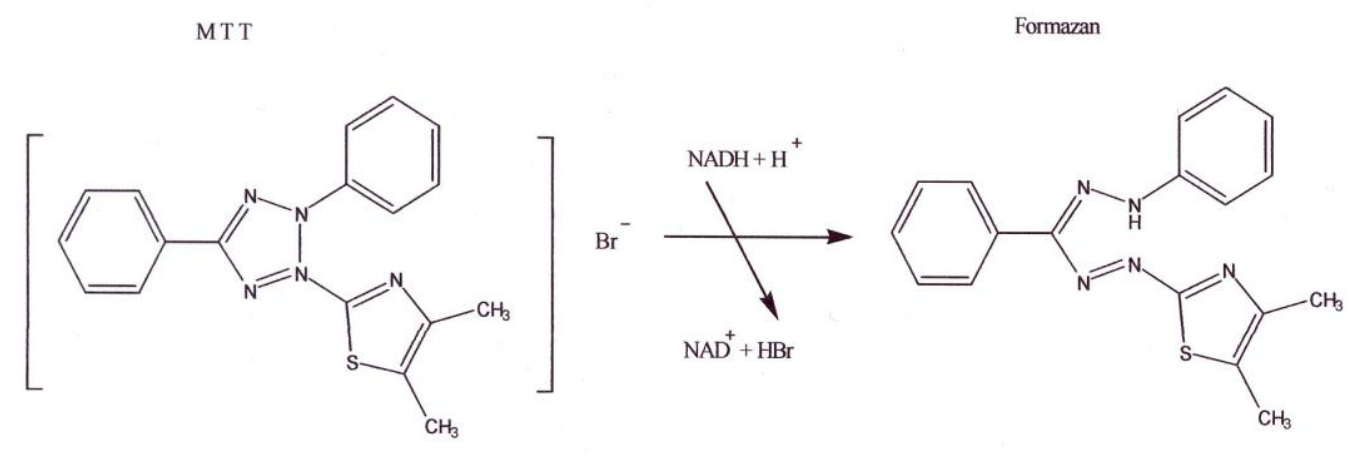

Gambar 1. Reaksi reduksi MTT menjadi formazan (Wyllie et al., 1980)

Data dari uji sitotoksisitas digunakan untuk menghitung kadar yang yang menyebabkan hambatan proliferasi sel $50 \%\left(\mathrm{IC}_{50}\right)$ dengan analisa probit. Persentase sel hidup setelah perlakuan pada masingmasing kadar dihitung dengan rumus:

$\%$ kematian sel $=\frac{\Sigma \text { Sel hidup pada kontrol }-\Sigma \text { Sel hidup pada sampel } \times 100 \%}{\Sigma \text { Sel hidup pada kontrol }}$

\section{Uji antiproliferatif}

Uji antiproliferatif dilakukan dengan menginkubasi sel dengan kepadatan $2 \times 10^{4}$ tiap sumuran dengan larutan uji. Pada uji ini jumlah sel awal yang digunakan sebesar 20.000 dengan absorbansi 0,287 dan perhitungan jumlah sel dilakukan pada jam-jam tertentu yaitu jam ke-0; ke-24; ke-48; ke-72 untuk mengetahui perkembangan pertumbuhannya. Sel di starvasi (dipuasakan) terlebih dahulu selama 24 jam dengan media kultur yang mengandung 0,5\% FBS (Fetal Bovine Serum). Selanjutnya sel ditumbuhkan di dalam plate dengan medium yang ditambahkan kontrol dan larutan uji dengan seri kadar yang tidak mematikan (di bawah $\mathrm{IC}_{50}$ ). Perlakuan sama seperti uji sitotoksisitas dengan menggunakan metode MTT. Sampling dilakukan pada jam ke 24, 48 dan 72. Data yang didapat berupa absorbansi sel hidup yang diperoleh dari hasil pengukuran dengan ELISA reader dengan panjang gelombang $550 \mathrm{~nm}$.

Analisis data pada uji antiproliferatif diperoleh dari data jumlah sel yang hidup pada jam ke-0, 24, 48 dan 72 dan dibuat grafik antara jumlah sel yang hidup dan lama waktu inkubasi (jam), kemudian ditentukan perbedaan waktu untuk mencapai jumlah dua kali sel awal.

Dari grafik antara log jumlah sel yang hidup dan lama waktu inkubasi (jam), kemudian ditentukan untuk mengetahui doubling time, caranya adalah dibuat persamaan regresi linear antara log jumlah sel yang hidup dan waktu dari masing-masing konsentrasi, kemudian dari persamaan tersebut dimasukkan nilai log jumlah dua kali sel awal sebagai nilai y maka akan diperoleh nilai x sebagai doubling time nya. Doubling time merupakan parameter antiproliferatif suatu bahan uji, jika doubling time nya lebih panjang dari kontrol negatif, maka dikatakan bahan uji mempunyai daya antiproliferatif. 


\section{Analisis Data}

Persentase kematian sel yang diperoleh pada uji sitotoksisitas dikonversikan ke dalam nilai probit melalui tabel. Dari data tersebut dibuat persamaan kurva regresi linear antara log konsentrasi dengan nilai probit. $\mathrm{IC}_{50}$ diperoleh dengan cara memplotkan nilai $\mathrm{y}=5$ sebagai probit ke dalam persamaan regresi linear. Antilog titik tersebut merupakan $\mathrm{IC}_{50}$ (Mursyidi, 1985).

\section{HASIL DAN PEMBAHASAN \\ Uji sitotoksisitas}

Uji sitotoksisitas merupakan uji secara in vitro yang pada umumnya menggunakan kultur sel. Uji ini merupakan uji pendahuluan untuk mengetahui potensi ketoksikan senyawa terhadap sel kanker dan dapat digunakan sebagai acuan untuk menentukan kadar pada uji selanjutnya yaitu uji antiproliferatif. Uji sitotoksisitas merupakan kelanjutan setelah senyawa tertentu diketahui bersifat toksik. Dari uji sitotoksisitas ini dapat diperoleh kadar yang menyebabkan penghambatan pertumbuhan sel sebesar 50\% dari populasi sel atau $\mathrm{IC}_{50}$ yang merupakan parameter ketoksikan sehingga dapat diketahui kisaran kadar yang berefek toksik terhadap sel kanker.

Pada uji sitotoksisitas ini dilakukan dengan metode pengamatan dengan MTT (3 - (4-5 dimetiltiazol-2-yl) - 2,5 - difenil tetrazolium bromid) yang merupakan garam tetrazolium yang sifatnya larut dalam air dengan menghasilkan larutan berwarna kuning. Sel hidup dapat mereduksi MTT, sedangkan sel mati tidak dapat mereduksi MTT karena enzim di dalam sel tidak berfungsi lagi. Prinsip dasarnya adalah kerja enzim mitokondria pada sel aktif yang memetabolisme garam tetrazolium, sehingga terjadi pemutusan cincin tetrazolium oleh enzim dehidrogenase yang menyebabkan tetrazolium berubah menjadi formazan yang tidak larut dan berwarna ungu (Mosmann, 1983). Intensitas warna ungu ini mempunyai korelasi langsung dengan jumlah sel yang hidup. Pada Gambar 1 dapat dilihat kristal formazan di bawah mikroskop dengan perbesaran $(10$ x 10 x 1,5).

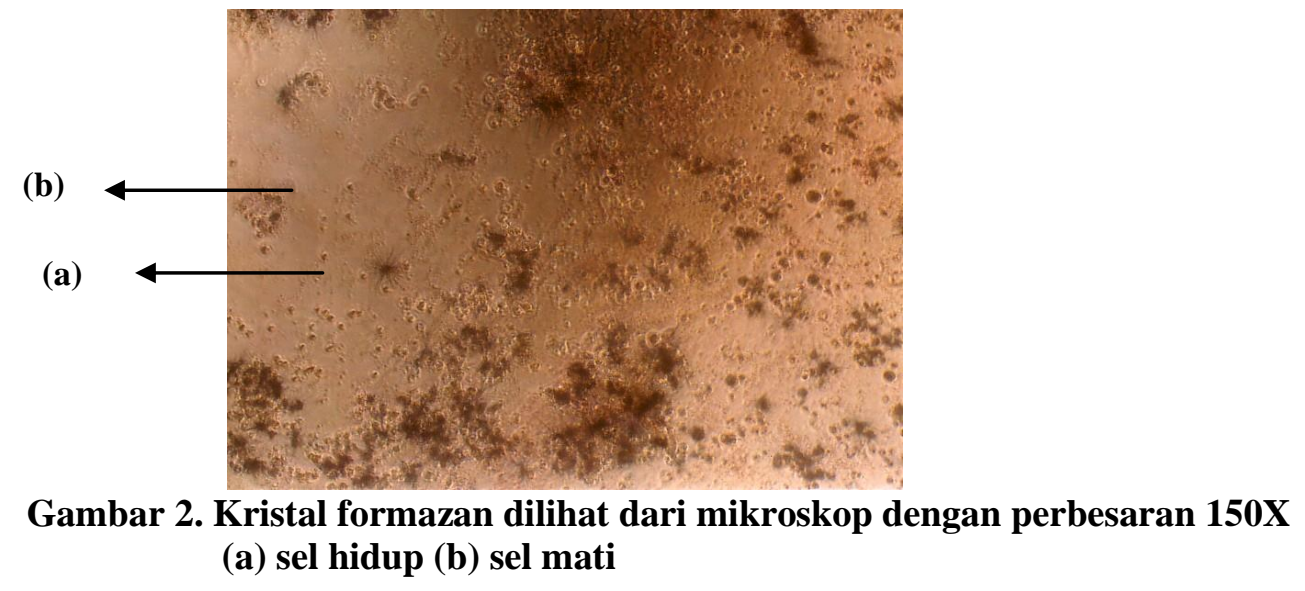

Intensitas warna ungu dan besarnya absorbansi diukur dengan ELISA reader (scanning multiwell spectrophotometer). Pengukuran dilakukan pada panjang gelombang $550 \mathrm{~nm}$, yaitu panjang gelombang optimum agar diperoleh pengukuran yang peka dan spesifik (Burgess, 1995). Intensitas warna ungu yang terbentuk sebanding dengan jumlah sel yang aktif melakukan metabolisme atau dengan kata lain sebanding dengan jumlah sel yang hidup. Semakin kuat intensitas warna ungu yang diperoleh absorbansi akan semakin besar. Hal ini menandakan bahwa banyak sel yang hidup dan bereaksi dengan garam tetrazolium, sehingga formazan yang terbentuk juga banyak. Absorbansi yang didapat kemudian digunakan untuk menghitung persentase kematian.

Dari hasil penelitian uji sitotoksisitas pada Tabel I menunjukkan bahwa perlakuan ekstrak etanol terhadap sel Raji dapat menginduksi kematian sel. Hal ini terlihat dengan adanya pengaruh kadar sediaan uji yang diberikan terhadap persentase kematian sel Raji. Semakin besar kadar senyawa uji yang diberikan pada suspensi sel, semakin besar pula persentase kematian sel Raji yang dihasilkan.

Dari data pada Tabel I dibawah dapat dihitung kadar yang menyebabkan penghambatan pertumbuhan $50 \%$ sel yang diuji $\left(\mathrm{IC}_{50}\right)$ dengan metode analisis probit. Data persentase kematian sel karena pengaruh perlakuan (sampel) dikonversikan dalam nilai probit, kemudian dibuat persamaan regresi linear antara log kadar dengan probit. Persamaan regresi yang diperoleh yaitu $\mathrm{y}=1,1081 \mathrm{x}+$ 
3,0359 dengan harga $\mathrm{r}=0,9103$. Harga $\mathrm{IC}_{50}$ diperoleh dengan memasukkan probit 5 ke dalam persamaan garis lurus tersebut, kemudian diperoleh harga $x$. Antilog dari harga $x$ merupakan $\mathrm{IC}_{50}$. Hasil pengujian menunjukkan ekstrak etanol daun Solanum nigrum memiliki nilai hambat pertumbuhan $50 \%$ sel Raji $\left(\mathrm{IC}_{50}\right)$ sebesar 59,22 $\mu \mathrm{g} / \mathrm{mL}$. Penelitian lain dari aktivitas antikanker buah Solanum nigrum, $\mathrm{L}$ terhadap sel HeLa menunjukkan penghambatan pertumbuhan dengan $\mathrm{IC}_{50}$ sebesar 265,0 $\mu \mathrm{g} / \mathrm{mL}$ (Patel et al, 2005). Dari evaluasi pengujian tersebut, maka ekstrak etanol daun Solanum nigrum, L mempunyai potensi sebagai antikanker terhadap sel Raji. Kandungan solanine yang terkandung dalam ekstrak leunca dilaporkan dapat menginduksi apoptosis melalui penurunan ekspresi Bcl-2 (Ji et al., 2008).

Tabel I. Hasil uji sitotoksisitas ekstrak etanol daun leunca (Solanum nigrum, L) terhadap sel raji

\begin{tabular}{|c|c|c|c|c|c|c|c|c|}
\hline \multirow[t]{2}{*}{ No } & \multirow{2}{*}{$\begin{array}{c}\text { Kadar } \\
(\mu \mathrm{g} / \mathrm{ml})\end{array}$} & \multirow{2}{*}{$\begin{array}{l}\text { Log } \\
\text { kadar }\end{array}$} & \multicolumn{3}{|c|}{$\%$ kematian sel } & \multirow{2}{*}{$\begin{array}{c}\text { Rata-rata \% } \\
\text { kematian }\end{array}$} & \multirow[t]{2}{*}{ Probit } & \multirow[t]{2}{*}{$\mathrm{IC}_{\mathbf{5 0}}$} \\
\hline & & & Rep I & Rep II & Rep III & & & \\
\hline 1 & 500 & 2,6989 & 97,44 & 96,66 & 93,90 & 96 & 6,75 & \\
\hline 2 & 250 & 2,3979 & 74,65 & 64,82 & 61,08 & 66,85 & 5,4355 & \\
\hline 3 & 125 & 2,0969 & 49,29 & 45,95 & 44,58 & 46,61 & 4,9122 & \\
\hline 4 & 62,5 & 1,7959 & 31,51 & 43,30 & 41,33 & 38,71 & 4,7113 & 59,22 \\
\hline 5 & 31,25 & 1,4949 & 31,11 & 33,47 & 38,78 & 34,45 & 4,599 & $\mu \mathrm{g} / \mathrm{mL}$ \\
\hline 6 & 15,625 & 1,1938 & 23,35 & 28,07 & 28,85 & 26,76 & 4,3828 & \\
\hline 7 & 7,8125 & 0,8928 & 18,24 & 24,92 & 22,96 & 22,04 & 4,2312 & \\
\hline 8 & 3,90625 & 0,5918 & 16,08 & 8,61 & 13,13 & 12,61 & 3,8505 & \\
\hline
\end{tabular}

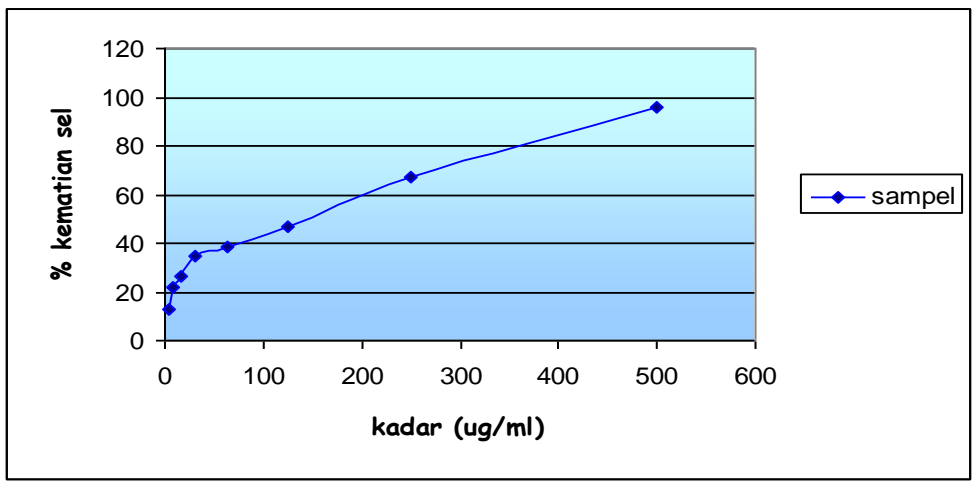

\section{Gambar 3. Grafik hubungan antara kadar ekstrak etanol daun leunca versus\% kematian sel}

Dari Gambar 3 terlihat bahwa persentase kematian sel Raji tertinggi yaitu sebesar $96 \%$ yang terjadi pada perlakuan sel Raji dengan ekstrak etanol daun leunca dengan kadar $500 \mu \mathrm{g} / \mathrm{mL}$ dan semakin menurun bila kadar ekstrak etanol yang diinkubasi bersama sel Raji menurun

\section{Uji Antiproliferatif}

Pada uji antiproliferatif ini dilakukan dengan menggunakan seri kadar yaitu $50 \mu \mathrm{g} / \mathrm{mL}$ dan 25 $\mu \mathrm{g} / \mathrm{ml}$ yang ditentukan dari harga $\mathrm{IC}_{50}$ pada uji sitotoksisitas, dimana kadar-kadar tersebut memiliki persentase kematian sel di bawah $\mathrm{IC}_{50}(59,22 \mu \mathrm{g} / \mathrm{mL})$. Pemilihan kadar dari larutan uji yang digunakan adalah di bawah kadar $\mathrm{IC}_{50}$ yang diperoleh pada uji sitotoksisitas agar sel dapat diamati pertumbuhan serta morfologinya karena sel tidak terlalu banyak yang mati. Apabila digunakan kadar di atas harga $\mathrm{IC}_{50}$ dikhawatirkan sel terlalu banyak yang mati sebelum 72 jam inkubasi sehingga pengamatan kinetika proliferasi tidak dapat dilakukan dan profil pertumbuhannya tidak terlihat.

Morfologi sel Raji pada kontrol dan perlakuan senyawa uji pada kadar $50 \mu \mathrm{g} / \mathrm{mL}$ dapat dilihat pada Gambar 4. Sel yang hidup pada kontrol terlihat tampak cerah (cemerlang), bentuknya bulat, bergerombol dan menempel di dasar sumuran sedangkan pada perlakuan terlihat adanya sel yang mati karena bentuknya sudah berubah dimana bentuknya sudah tidak bulat lagi dan tampak gelap.

Uji antiproliferatif ini dilakukan dengan metode MTT. Data yang diperoleh berupa absorbansi sel hidup. Sampel yang berwarna dapat memberikan absorbansi sehingga absorbansi yang terbaca tidak hanya warna ungu yang sebanding dengan jumlah sel yang hidup tapi juga warna dari sampel, sehingga diperlukan adanya kontrol sampel untuk mengeliminasi pengaruh absorbansi dari sampel karena 
berwarna. Hasil absorbansi perlakuan dikurangi absorbansi dari kontrol sampel, kemudian dikonversikan ke dalam jumlah sel hidup. Data jumlah sel hidup dan absorbansi nya dapat dilihat pada Tabel II.

Dari Tabel II kemudian dibuat persamaan regresi linear antara jumlah sel hidup dan absorbansi yang digunakan untuk mengkonversikan absorbansi sel hidup dari setiap perlakuan persatuan waktu dan diperoleh persamaan kurva baku yaitu: $y=6,528.10^{-6} x+0,124$ dengan harga $\mathrm{r}=0,9655$. Hasil absorbansi sel hidup pada masing-masing perlakuan persatuan waktu, yaitu pada kontrol sel, sampel kadar 25 dan $50 \mu \mathrm{g} / \mathrm{ml}$ dimasukkan pada persamaan diatas sehingga diperoleh data jumlah sel hidup (Tabel III).

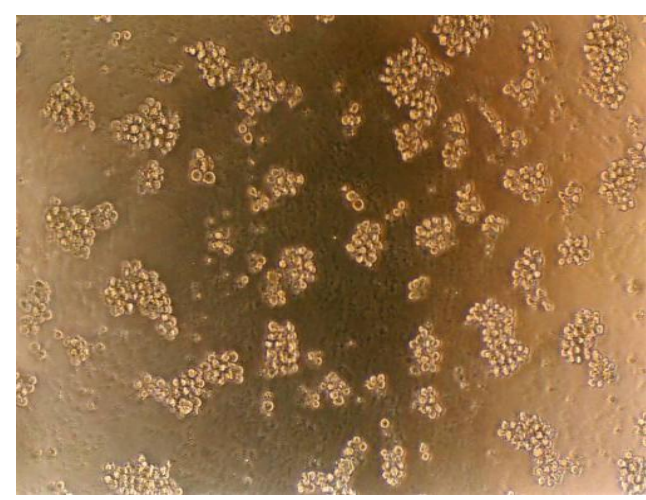

(A)

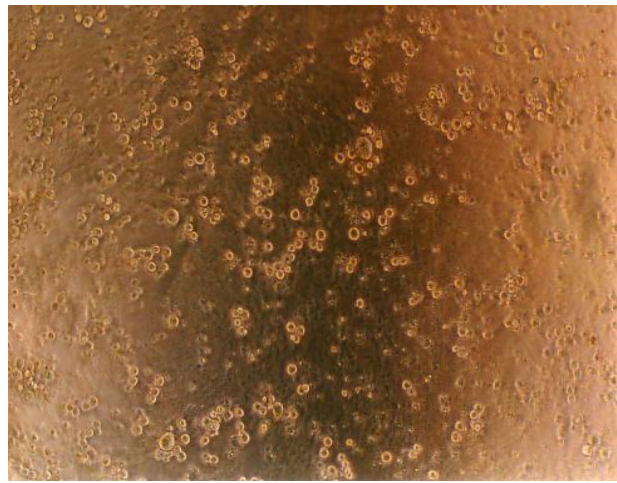

(B)

Gambar 4. Morfologi sel Raji dalam sumuran dengan perbesaran 150X setelah diinkubasi 24 jam dengan perlakuan ekstrak etanol daun leunca (Solanum nigrum,L.). Kontrol sel (A); Sampel kadar 50 $\mu \mathrm{g} / \mathrm{mL}$ (B)

Tabel II. Variasi jumlah sel dan absorbansi yang ditetapkan dengan metode MTT pada panjang gelombang 550nm

\begin{tabular}{cc}
\hline Jumlah sel hidup & Absorbansi \\
\hline 80.000 & 0,605 \\
60.000 & 0,536 \\
40.000 & 0,440 \\
20.000 & 0,287 \\
10.000 & 0,126
\end{tabular}

Tabel III. Hasil absorbansi dan jumlah sel hidup tiap perlakuan yaitu pada kontrol sel, sampel kadar $50 \mu \mathrm{g} / \mathrm{mL}, 25 \mu \mathrm{g} / \mathrm{mL}$ persatuan waktu.

\begin{tabular}{cccccccccc}
\hline Perlakuan & \multicolumn{2}{c}{ Jam ke-0 } & \multicolumn{2}{c}{ Jam ke-24 } & \multicolumn{2}{c}{ Jam ke-48 } & \multicolumn{2}{c}{ Jam ke-72 } \\
\cline { 2 - 9 } & $\begin{array}{c}\text { Abs sel } \\
\text { hidup }\end{array}$ & $\begin{array}{c}\text { Jmlh } \\
\text { sel } \\
\text { hidup }\end{array}$ & $\begin{array}{c}\text { Abs sel } \\
\text { hidup }\end{array}$ & $\begin{array}{c}\text { Jmlh } \\
\text { sel } \\
\text { hidup }\end{array}$ & $\begin{array}{c}\text { Abs sel } \\
\text { hidup }\end{array}$ & $\begin{array}{c}\text { Jmlh } \\
\text { sel } \\
\text { hidup }\end{array}$ & $\begin{array}{c}\text { Abs sel } \\
\text { hidup }\end{array}$ & $\begin{array}{c}\text { Jmlh } \\
\text { sel } \\
\text { hidup }\end{array}$ \\
\hline Kontrol sel & 0,287 & 20.000 & 0,347 & 34.160 & 0,410 & 43.811 & 0,471 & 53.156 \\
$\begin{array}{c}\text { Sampel kadar } \\
50 \mu \mathrm{g} / \mathrm{mL}\end{array}$ & 0,287 & 20.000 & 0,337 & 32.628 & 0,424 & 45.955 & 0,333 & 32.016 \\
$\begin{array}{c}\text { Sampel kadar } \\
25 \mu \mathrm{g} / \mathrm{mL}\end{array}$ & 0,287 & 20.000 & 0,346 & 34.007 & 0,399 & 42.126 & 0,372 & 37.990 \\
\hline
\end{tabular}


Dari Tabel III dapat dilihat bahwa jumlah sel pada kontrol sel pertumbuhan selnya semakin naik dengan bertambahnya waktu inkubasi, sedangkan pada perlakuan dengan ekstrak menunjukkan penurunan pertumbuhan sel dengan bertambahnya waktu inkubasi.

Setelah jumlah sel hidup diketahui pada jam ke-0, 24, 48, dan 72 kemudian ditentukan kemampuan penghambatan proliferasi sel. Efek antiproliferatif terhadap sel Raji dapat dianalisis dengan cara membandingkan waktu yang diperlukan sel pada masing-masing perlakuan dengan kontrol untuk menggandakan dirinya menjadi dua kali lipat. Penghitungan doubling time dilakukan dengan menggunakan persamaan regresi antara waktu inkubasi dan log jumlah sel hidup, kemudian dari persamaan tersebut dimasukkan nilai log jumlah dua kali sel awal sebagai nilai $y$, maka akan diperoleh nilai $x$ sebagai doubling time nya.

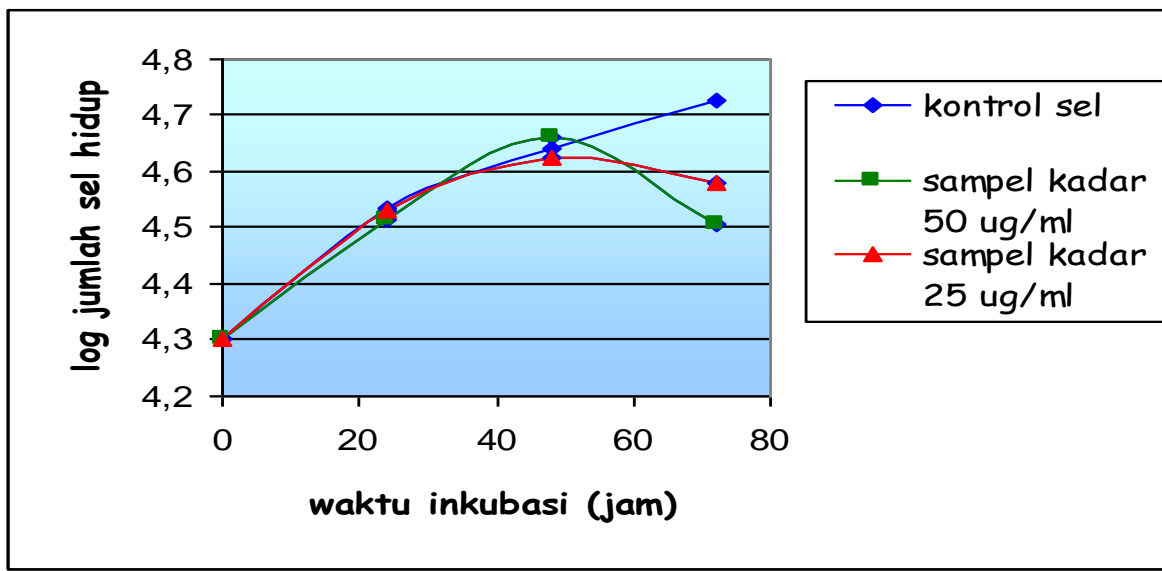

\section{Gambar 5. Grafik hubungan waktu inkubasi versus log jumlah sel hidup pada kontrol sel dan sampel kadar 50 dan $25 \mu \mathrm{g} / \mathrm{ml}$}

Pada grafik terlihat pada kontrol sel (RPMI 1640) tetap menunjukkan kenaikan pertumbuhan sel karena tidak adanya perlakuan dengan senyawa uji, ini berarti sel mampu beradaptasi dengan lingkungan. Namun pola pertumbuhan sel dengan adanya senyawa uji terlihat pada profil grafik dimana ada kenaikan jumlah sel hidup sampai jam ke-48, namun setelah jam ke-48 terjadi penurunan jumlah sel hidup hingga jam ke-72. Pada perlakuan sampel kadar $50 \mu \mathrm{g} / \mathrm{mL}$ terlihat adanya grafik yang menurun lebih tajam dari jam ke-48 hingga jam ke-72 dibandingkan grafik pada perlakuan sampel kadar $25 \mu \mathrm{g} / \mathrm{mL}$. Hal ini menunjukkan tidak adanya pertumbuhan sel Raji yang kemungkinan disebabkan karena sel mengalami stress dengan adanya penambahan ekstrak kadar tinggi yang diduga dapat mematikan sel sampai pengamatan pada jam ke-72, karena tidak adanya pertumbuhan sehingga dapat ditarik kesimpulan bahwa sel mengalami kematian.

Pada uji antiproliferatif ini dilakukan perhitungan untuk mengetahui waktu yang diperlukan sel untuk membelah menjadi dua kali lipatnya. Penghitungan doubling time yang merupakan parameter dari uji antiproliferasi dilakukan dengan menggunakan persamaan regresi linear yang diperoleh dengan cara memplotkan waktu inkubasi versus log jumlah sel hidup kemudian hasilnya dimasukkan ke dalam rumus:

$$
\mathrm{X}=\frac{\mathrm{Y}-\mathrm{A}}{\mathrm{B}}
$$

di mana: $\mathrm{X}=$ doubling time (jam)

$$
\begin{aligned}
& \mathrm{A}=\text { Intersep } \\
& \mathrm{B}=\text { Slope }
\end{aligned}
$$

Harga doubling time dapat dilihat dari harga slope persamaan yang diperoleh. Semakin besar harga slope maka semakin singkat doubling time-nya dan sebaliknya. Harga slope pada perlakuan senyawa uji kadar 50 dan $25 \mu \mathrm{g} / \mathrm{mL}$ lebih kecil dari harga kontrol sel yang berarti harga doubling time sampel lebih panjang. Hasil perhitungan dapat dilihat pada Tabel IV. 
Tabel IV. Hasil pengamatan regresi linear dan harga doubling time sel raji pada berbagai perlakuan

\begin{tabular}{llcc}
\hline \multicolumn{1}{c}{ Perlakuan } & \multicolumn{1}{c}{ Persamaan } & r & Doubling time (jam) \\
\hline Kontrol sel & $\mathrm{y}=0,005763 \mathrm{x}+4,3428$ & 0,9705 & 44,98 \\
Kadar $25 \mu \mathrm{g} / \mathrm{mL}$ & $\mathrm{y}=0,003863 \mathrm{x}+4,3702$ & 0,8315 & 60,00 \\
Kadar $50 \mu \mathrm{g} / \mathrm{mL}$ & $\mathrm{y}=0,00317 \mathrm{x}+4,3815$ & 0,6616 & 69,56 \\
\hline
\end{tabular}

Pada Tabel IV dapat dilihat bahwa semakin tinggi kadar ekstrak yang diberikan maka semakin besar harga doubling time yang didapat. Harga doubling time pada kontrol sel adalah 44,98 jam sedangkan doubling time sampel lebih tinggi yaitu pada perlakuan kadar $50 \mu \mathrm{g} / \mathrm{mL}$ doubling time-nya sebesar 69,56 jam, sedangkan pada kadar $25 \mu \mathrm{g} / \mathrm{mL}$ harga doubling time-nya menjadi 60,00 jam. Berarti pada perlakuan dengan menggunakan zat uji dapat memperpanjang doubling time sel Raji dibanding dengan kontrol sel. Dari hasil penelitian tersebut dapat menunjukkan adanya efek antiproliferasi dari ekstrak etanol daun leunca dengan menunda doubling time / menghambat proliferasi dimana besarnya penundaan tergantung kadar ekstrak yang diberikan. Semakin tinggi kadar ekstrak, semakin tinggi pula terjadinya hambatan pada pertumbuhan sel Raji, sehingga dapat disimpulkan bahwa ekstrak etanol daun leunca (Solanum nigrum, L.) mempunyai sifat antiproliferasi melalui mekanisme penundaan waktu penggandaan. Kandungan glikoprotein dari Solanum nigrum, L dapat mengaktifkan caspase-3 melalui sitokrom-c di sel HT-29. Glikoprotein yang diisolasi dari leunca menunjukkan aktivitas sitotoksik pada sel kanker kolon (Lee, 2005).

\section{KESIMPULAN}

Ekstrak etanol daun leunca (Solanum nigrum, L.) memliki potensi sitotoksisitas terhadap sel Raji yang dinyatakan dengan nilai $\mathrm{IC}_{50}$ sebesar $59,22 \mu \mathrm{g} / \mathrm{mL}$ dan memiliki aktivitas antiproliferatif terhadap sel Raji yang ditunjukkan dengan harga doubling time pada kontrol sel 44,98 jam, sedangkan perlakuan dengan kadar 25 dan $50 \mu \mathrm{g} / \mathrm{mL}$ harga doubling time nya menjadi 60,00 jam dan 69,56 jam.

\section{DAFTAR PUSTAKA}

Burgess, G. W., 1995. Prinsip dasar elisa dan variasi konfigurasinya, dalam burgess, Elisa Technology In Diagnosis and Research, diterjemahkan oleh Wayan, T.A., Gadjah Mada University Press, Yogyakarta, 506.

Dalimartha, S., 2006, Ramuan Tradisional Untuk Pengobatan Kanker, Penebar Swadaya, Jakarta 1-3, $67-$ 68

Hukom, R.A., 2005, Kelenjar yang membunuh, Semijurnal Farmasi dan Kedokteran Ethical Digest. Penerbit Etika Media Utama, Jakarta. 50-57

Hu K, Dong A, Jing Y, Iwasaki S, Yao X, 1999., Antineoplastic agents III : steroidal glycosides from Solanum nigrum. Planta medica., 65(1): 35-38

Ji, YB., Gao, SY., Ji, CF., Zou, X, 2008. Induction of apoptosis in HepG2 cells by solanine and Bcl-2 protein. Journal of Ethnopharmacology. 115: 194-202

Junedi, S., Hermawan, A., Ikawati, M., Meiyanto, E., 2010, Standard Operating Procedure, Cancer Chemoprevention Research Center, Fakultas Farmasi Universitas Gadjah Mada, Yogyakarta.

Katzung, B.G., 2004, Farmakologi Dasar dan Klinik, Edisi 8, diterjemahkan oleh Bagian Farmakologi Fakultas Kedokteran Universitas Airlangga, Penerbit Salemba Medika, Jakarta, 298, 317-322, 340-341.

Kemenkes, 2015. Pusat Data dan Informasi Kementerian Kesehatan RI.

Lee, S.J., Ko, K.H., Lim, K.T., 2005, Glycine-and proline-rich glycoprotein isolated from Solanum nigrum Linne activates caspase-3 through cytochrom c in HT-29 cells., Oncology reports, 14, no 3, pp. 789-796.

Liang, C.H., Shiu L.Y., Chang L.C., Sheu H.M., Tsai E.M., and Kuo K.W., 2008, Solamargine enhances HER2 expression and increases the susceptibility of human lung cancer H661 and H69 cells to trastuzumab and epirubicin, Chem Res. Toxicol., 21 (2): 393-399.

Liu Feng Li., Liang Chia-Hua., Shiu Li-Yen., Huang Yu-Sheng., Kuo Kou-Wha., 2004. Action of solamargine on TNFs and cisplatin-resistant human lung cancer cells, Biochemical and Biophysical Research Communication. 322 : 751-758. 
Meiyanto, E., Sismindari., Chandra, L., Moordiani., 2003, Penelitian efek antiproliferatif ekstrak etanol daun dan kulit batang tanaman cangkring (Erythrina fusca Lour.) terhadap sel heLa, Majalah Farmasi Indonesia, 14(3):124-131

Mursyidi, A., 1985, Statistik Farmasi dan Biologi, Ghalia Indonesia, Jakarta, 157.

Mosmann, T., 1983, Rapid colorimetric assay for cellular growth and survival: application to proliferation and citotoxicity assay, Journal of Immunological Method, 55-63, 65.

Patel, S., Gheewala, N., Suthar, A., Shah, A., 2009. In-vitro cytotoxicity activity of Solanum nigrum extract against hela cell line and vro cell line. International Journal of Pharmacy and Pharmaceutical Science. 1:38-46

Tai, CJ., Wang, CK., Lin,YF., Lin,CS., Jian,JY., Chang, YJ., Chang,CC., 2013, Aqueous extract of solanum nigrum leaves induces autophagy and enhances cytotoxicity of cisplatin, doxorubicin, docetaxel and 5-fluorouracil in human colorectal carcinoma cells. Hindawi Publishing Corporation Evidence-Based Complementary and Alternative Medicine, 12.

Wyllie, A. H., Kerr, J. F., Curie, A. R., 1980, Cell Death : The significance of a poptosis, Int. Rev Cytol, 68: 251-306. 